\title{
Evaluation of P-101 "Orientation
} to Occupational Safety

Compliance in DOE" Pilot

Course Taught in Richland, Washington

\section{February 19 - March 1, 1991}

R. W. Vinther

April 1991

Prepared for the

U.S. Department of Energy under Contract DE-AC06-76RLO 1830

Pacific Northwest Laboratory

Operated for the U.S. Department of Energy

by Battelle Memorial Institute 


\title{
DISCLAIMER
}

This repor was prepared as an account of work sponsored by an agency of the United States Government. Neither the United States Government nor any agency thereof, nor Battelle Memorial Institute, nor any of their employees, makes any warranty, expressed or implied, or assumes any legal liability or responsibility for the accuracy, completeness, or usefulness of any information, apparatus, product, or process disclosed, or represents that its use would not infringe privately owned rights. Reference herein to any specific commercial product, process, or service by trade name, tradernark, manufacturer, or otherwise does not necessarily constitute or imply its endorsement, recommendation, or favoring by the United States Government or any agency thereof, or Battelle Memorial Institute. The views and opinions of authors expressed herein do not necessarily state or reflect those of the United States Government or any agency thereof.

\author{
PACIFIC NORTHWEST LABORATORY \\ operated by \\ BATTELLE MEMORIAL INSTITUTE \\ for the \\ UNITED STATES DEPARTMENT OF ENERGY \\ under Contract DE-ACO6-76RLO 1830
}

Printed in the United Stales of America

Available to DOE and DOE contractors from the

Office of Scientific and Technical Information, P.O. Box 62, Oak Ridge, TN 37831; prices available from (615) 576-8401. FTS 626-8401.

Available to the public irom the National Technical information Service, U.S. Department of Commerce, 5285 Port Royal Rd., Springfield, VA 22161. 
PNL -7677

UC-900

EVALUATION OF P-101 "ORIENTATION TO

OCCUPATIONAL SAFETY COMPLIANCE IN DOE"

PILOT COURSE TAUGHT IN RICHLAND, WASHINGTON

FEBRUARY 19 - MARCH 1, 1991

R. W. Vinther

April 1991

Prepared for the U.S. Department of Energy under Contract DE-AC06-76RLO 1830

Pacific Northwest Laboratory

Richland, Washington 99352 


\section{SUMMARY}

This report summarizes trainee evaluations for the DOE Safety Training Institute's pilot course, "Orientation to Occupational Safety Compliance in DOE", which was conducted February 19, 1991 - March 1, 1991 at Richland, Washington.

Trainee evaluations were very favorable. They reported that their know1edge and familiarity with the OSHA standards were greatly enhanced through the presentation of the course. The first part of the report summarizes the quantitative course evaluations that trainees provided upon completion of the course and provides a transcript of the trainees' written comments In Appen$\operatorname{dix} A$. The second part summarizes results from the trainee knowledge survey and the final examination designed to measure the knowledge gained from the course. The third part of the report summarizes course modifications and recommendations for improvement. 
- 


\section{CONTENTS}

SUMMARY

1.0 SUMMARY OF TRAINEE COURSE EVALUATIONS . . . . . . . . . . 1.1

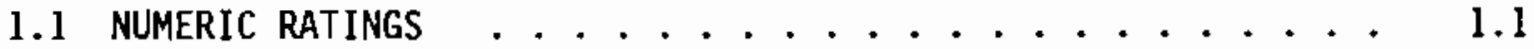

1.2 WRITTEN COMMENTS . . . . . . . . . . . . . . . . 1.4

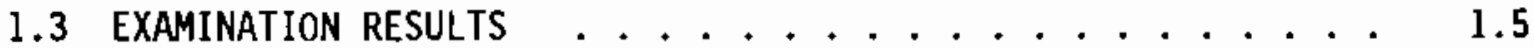

1.3.1 Trainee Knowledge Surveys . . . . . . . . . 1.5

1.3.2 Final Examination .............. 1.5

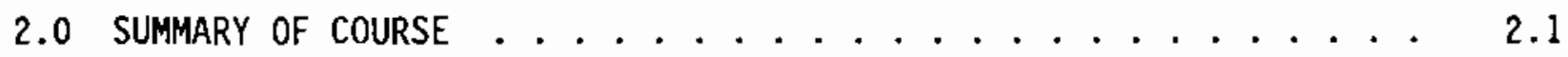

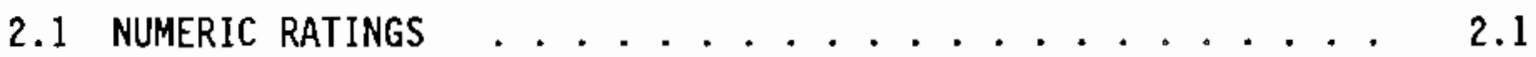

2.1.1 Written Comments ................ 2.1

2.1.2 Examinations ............... 2.1

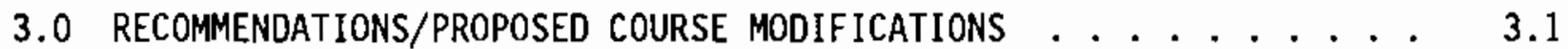

APPENDIX A - ORIENTATION TO OCCUPATIONAL SAFETY COMPLIANCE

IN DOE ....................... A.1

APPENDIX B - TRAINEE EVALUATION FORM . . . . . . . . . . . . B.l 



\subsection{SUMMARY OF TRAINEE COURSE EVALUATIONS}

This pilot course was conducted at Richland, Washington. Three instructors and a course administrator presented the course to seven (7) Hanford contractor and DOE-RL employees.

\subsection{NUMERIC RATINGS}

Seven trainees completed a course evaluation form upon finishing the course. The first rating area of the form covered five (5) items dealing with course content; the second rating area covered three (3) items dealing with testing materials; and the third rating area covered thirty-one (31) items specifically associated with course topic areas.

For the first and second rating areas, respondents were instructed to rate the degree to which they agreed or disagreed with each statement using a five-point scale with 1 (10w) and anchored to "strongly disagree" and 5 (high) anchored to "strongly agree". The ratings are as follows:

\section{COURSE CONTENT RATINGS}

1. Developed specific skills and competencies in occupational safety compliance that I can use on the job.

$$
\text { Average C1ass Rating - } \underline{4.71}
$$

2. Gained a greater understanding of 29 CFR 1910, Occupational Safety and Health Standards.

$$
\text { Average Class Rating - } \underline{4.57}
$$

3. Gained factual knowledge about Federal safety and health program requirements.

$$
\text { Average Class Rating - } \underline{4.43}
$$

4. Would recommend this course to others.

$$
\text { Average Class Rating - } \underline{4.71}
$$

5. Compliance knowledge gained from this course will make work environments safer. 
The average class rating for the course content area was 4.60 . This high rating reinforces the applicability of the course content to the trainees' interests and work environments.

\section{TESTING MATERIALS}

1. The final test was a good measure of the knowledge gained in this course.

$$
\text { Average Class Rating - } \underline{4.50}
$$

2. The final test (and pre-test) thoroughly covered materials and instruction presented in the course.

$$
\text { Average Class Rating - } \underline{4.57}
$$

3. The finat test (and pre-test) should become a permanent part of this course.

$$
\text { Average Class Rating - } \underline{4.71}
$$

The average class rating for the testing material was 4.60. Trainees felt that the testing material was applicable and a good measure of what was presented.

The third rating area asked the respondents to rate the value of each of the 31 topic areas using a five-point scale with 1 (Unsatisfactory), 2 (Satisfactory), 3 (Good), 4 (Very Good), or 5 (Excellent). The following are the average class ratings that dealt with topic content as well as with the value of the instructor:

\section{IOPIC AREA RATINGS}

\section{Topic Area}

1. Introduction to DOE Safety and Health Program

2. Introduction to OSHA standards

3. Hazardous Materials -- flammable and combustible materials

4. Materials Handling and Storage

5. Means of egress

\section{Content Instructor}

$\begin{array}{ll}4.33 & 4.17\end{array}$

4.33

4.17

3.83

3.33

$4.17 \quad 4.17$

$4.50 \quad 4.00$ 
6. Fire Protection

7. Compressed gas/air equipment

8. Welding, cutting and brazing

9. Electrical Safety

10. Machine guarding

11. Lock out Tag out (LOTO)

12. Hand and portable tools

13. Construction safety

14. Walking-Working Surfaces

15. Powered platforms

16. Toxic and hazardous substances

17. Carcinogen policy and model standards

18. Material Safety Data Sheets (MSDS)

19. Laboratory Safety

20. Personal protective equipment

4.00

21. Medical and first aid

22. Occupational health and environmental control

23. Confined space entry

24. General and environmental controls

25. DOE accident/injury/illness reporting system

26. Accident investigation procedures

27. Inspection responsibilities and procedures

4.14

4.29

28. Introduction to communications and human reiations 
Topic Area

29. Safety inspection field exercise

30. Presentation workshop, Part I

31. Presentation workshop, Part II
Content Instructor

$4.00 \quad 4.17$

$4.17 \quad 4.17$

$4.00 \quad 4.00$

The overall average class rating for specific topic content was 4.06. The overall average class rating for the instructors in general was 4.04 .

\subsection{WRITTEN COMMENTS}

After providing numeric course evaluations, participants provided written comments about the course. Written comments were transcribed and are presented in their entirety in Appendix $A$ and are summarized below.

\section{Expectations}

The course exceeded some of the trainees' expectations. Trainees learned a great deal about OSHA regulations, specifically 29 CFR 1910 and 1926.

\section{Most helpful topics}

Health topics, construction standards and inspections were looked at as helpful topics.

\section{Least helpful topics}

Mention was made to reflect the need for making the student books match the slides. Some mentioned that it would have been better to use the official Code of Federal Regulations book rather than the Commerce Clearing House, Inc.

\section{Suggestions for improvement}

Some felt more emphasis should be placed on looking up regulations for specific examples/situations. Utilize the most up to date standards books. Mention was made to not cover so much ground in some areas in so little time. Instruction could be supplemented by showing examples of equipment or items being discussed in the various topic areas. Some felt the classroom was too uncomfortable and confined. Some were distracted by the lectures "revolving" 
around the overhead projectors. It was emphasized that the instructors should continue to show enthusiasm when sharing information from reference materials and their own past experiences.

\section{Other types of training courses}

Some ideas offered for future safety training activities included courses associated with Hanford cleanup, research work on Tiger Team findings, and a fire protection class.

\section{other comments}

The comments were very favorable towards the entire course. Respondents felt that it was interesting and that the course administrator did a good job of focusing the course on DOE.

\subsection{EXAMINATION RESULTS}

Two tests were administered in this course. On the first day, a trainee knowledge survey (pre-test) was taken by five (5) trajnees. On the last day of the course, a final examination was administered to seven (7) trainees. Summaries of the examinations (survey) results are shown below:

\subsubsection{Irainee Knowledge Surveys}

Five (5) trainees took the twenty-five (25) question trainee knowledge survey. There were twenty-three (23) multiple choice questions and two (2) questions that required the trainees to list the appropriate answers. The test data showed that four (4) specific questions were missed by all the trainees. These were deemed not OSHA standard specific and were not used in the final examination.

The scores ranged from $36 \%$ to $41 \%$ with the average score being $38.8 \%$. of the twenty-five (25) questions asked on the survey, only three (3) questions were missed by all trainees.

\subsubsection{Final Examination}

Seven (7) trainees took the thirty-five (35) question final examination. The test was comprised of twenty-one (21) new questions and fourteen (14) questions from the trainee knowledge survey given on the first day of class. 
There were twenty-eight (28) multiple choice questions and seven (7) questions that required the trainees to 1 ist the appropriate answers.

The scores ranged from $86 \%$ to $97 \%$ with the average score being $92.4 \%$. of the 35 questions asked on the final examination, no question was missed by all of the trainees. One question was missed by six of the trainees. 


\subsection{SUMMARY OF COURSE}

\section{I NUMERIC RATINGS}

Numeric course ratings provided by trainees were generally positive and show that the course material and instruction was very effective.

The average class ratings for individual questions associated with the applicability of course content ranged from 4.43 to 4.71 . The overall average class rating for the course content area was 4.60 . This high rating reinforces the applicability of the course content to the trainees' interests and work environments.

The average class ratings for individual statements concerning the effectiveness of the testing materials ranged from 4.50 to 4.71 . The overall average class rating for the testing material was 4.60 . Trainees felt that the examinations were applicable and a good measure of what was presented.

Specific topic areas were rated as to the value of content as well as the value of instructor ability. Average class ratings for specific topic area content ranged from 3.40 to 4.67 . The overall average class rating for topic content was 4.06 .

The average class ratings for instructor ability ranged from 3.33 (in the area of Hazardous Materials) to 5.00 (in the area of Material Safety Data Sheets). The overall average class rating for the instructors was 4.04 .

\subsubsection{Written Comments}

Written comments supported the positive numeric ratings. Trainees felt that the class was interesting, applicable to their needs and was well worth the time and effort. Most would highly recommend this course to others who needed OSHA compliance familiarity. It was noted that DOE and DOE contractor management must make a strong comnitment to support this nine day course.

\subsubsection{Examinations}

Examinations were a good indicator of knowledge gained from the course. There was a vast improvement in scores from the trainee knowledge survey to the final examination. The scores on the final examination showed an average 
improvement of 56 percentage points from the average scores of the trainee knowledge survey. Trainees indicated that maintaining similar tests in the future would be a good measure of the effectiveness of the training course. 


\subsection{RECOMMENDATIONS/PROPOSED COURSE MODIFICATIONS}

The pilot course was viewed as very successful by trainees as well as by the instructors and the course coordinator. Evaluations indicate that the course structure should be maintained in its present format and length. Field exercises should continue to be integrated into future courses. This will require strong coordination with other DOE sites to assure that equivalent facilities are provided for exercises and drills on the OSHA standards. In general, trainees felt that additional time should be spent on this portion of the course.

A11 numeric average class ratings were 3 (Good) or higher. The average class ratings that were under 4 (very good) indicate that improvements could be made in those topic areas which are listed below:

- Hazardous Materials

- Fire Protection

- Compressed gas/air equipment

- Welding, cutting and brazing

- Electrical Safety

- Construction Safety

- Laboratory Safety

- Medical and first aid

- Occupational health and environmental control

- Confined space entry

- General environmental controls

- DOE accident/injury/illness reporting system

- Accident investigation procedures

Efforts should be made to upgrade training materials to ensure consistency between student handouts and the visual aids used in the course. More slides and videos should be added to the course to illustrate specific 
examples of OSHA violations (i.e., machine guarding, fall protection, PPE, etc.). Demonstration of equipment and materials (i.e., testing equipment, personal protective equipment, portable tools, etc.) should be incorporated into the course where possible.

Trainee evaluations and verbal feedback indicate that additional courses should be considered for development by the Safety Training Institute in the following areas:

- Fire Safety

- Construction Safety

- Electrical Safety

- Lock Out Tag Out procedures

- Machine Guarding

- "How to read" the OSHA standards 
APPENDIX A

\section{TRAINEE EVALUATION FORM}

"ORIENTATION TO OCCUPATIONAL SAFETY COMPLIANCE IN DOE" FEBRUARY 19,1991 - MARCH 1, 1991--RICHLAND, WASHINGTON

EVALUATION COMMENTS 
APPENDIX A

IRAINEE EVALUATION FORM

"ORIENTATION TO OCCUPATIONAL SAFETY COMPLIANCE IN DOE"

FEBRUARY 19, 1991 - MARCH 1, 1991--RICHLAND, WASHINGTON

EVALUATION COMMENTS

Trainee Comments

Please briefly describe how your expectations of this course were or were not met.

I gained a working knowledge of the use of 1910-1926, which is what I really needed. I appreciate the efforts of all the teachers and their concern in getting the material across.

I had little knowledge of this training before 1 came, but got a lot out of the class to use at a later time.

This course has the potential to exceed the DSHA course because it focuses more on $D O E$ issues.

This abbreviated course exceeded my expectations.

I learned a lot of the OSHA regulations, even though, the coverage of some of the topics was just cursory.

The most helpful topics covered or activities presented in this course were:

The inspections, the presentation and the topics were very helpful.

I got a lot out of most all topics, some I will be able to use much more then others.

Construction standard section was appreciated and though it wasn't in great detail it was a good introduction.

The health topics were my weaknesses and this course filled these needs.

The least helpful things discussed or done were:

Make books match slides.

There was something to be gotten out of all material discussed. 
Using the CCH Inc book vs. the CFR book - since I only use the latter, it is harder to transfer learned data.

The class on construction safety was or will be of little use for me.

Hore emphasis should be given to:

Electrical safety, getting into the book to look up things, so we will be more familiar with the book.

Looking up regulations.

DOE films, examples.

DOE examples with visual aids such as a DOE facility and findings on it (visual)/Tiger Team.

Lock and Tag, Machine Guarding, Construction Safety.

Less emphasis should be given to:

Accident/injury/illness reporting/office safety.

What I had hoped would be covered but wasn't mentioned was:

No comments.

What specific suggestions do you have for improving future sessions. What the presenters might do?

Not revolving whole lectures around the overhead projectors. This gets very boring and hard to pay attention.

Get a bigger presentation hall.

Cite specific examples. Describe more fully machines/equipment where the standard would fit.

Have same book as slides used, try not to cover so much ground in some areas in so little time.

Check to make sure the OSHA Standard cited are correct referenced/ bring in some testing equipment to show how they work in compliance such as in testing electrical devices. 
Other materials to supplement or substitute for the provided handouts?

More videos.

Physical pieces representing the item covered in the presentation. Ex materials handling and storage. Show what this is.

I liked Carl's personal interest in past literature and how he shared it $w /$ the class. This kept my interest up and is something other instructors may try.

Need to have the most up to date standards books and possibly copies of any new proposals.

Daily schedule/timing of activities, worktime?

Start class at normal work time (7:30 etc.) and possibly quiet earlier to allow people to return to their office to check mail, on program etc.

Lunch hours were very nice but if it came down to swing time, not really necessary.

I thought they were about right.

Two week, maybe eight days, is adequate for the course. There has to be a commitment by management to support this timely effort.

Facilities/training room arrangements?

Chairs are uncomfortable.

Just fine.

What other types of safety training courses would you like to see available?

A1l types that will deal with the Hanford clean-up.

A whale session - 8 hrs to nothing but looking up tiger team findings. This would help in memorizing standards and accuracy in looking standards up.

Fire Protection Class.

Any further comments?

I liked the class. I thought it was well presented and it kept my interest up. 
For a class of this length, it was kept interesting. For me this was a good class.

I feel that the course captured some of the good things from the OSHA course. I think that the training coordinator has done a good job with the course, focusing on DOE. I think that it is very important however, that the right audience be targeted. Need to get rid of the Commerce Clearing House Inc OSHA edition, it is not very useful. 
APPENDIX B

TRAINEE EVALUATION FORM 
TRAINEE EVALUATION FORM

Orientation to

Occupational Safety Compliance in DOE
Date

Name

Title

Please list your major job duties.

What do you expect to gain from this course?

Briefly describe your safety training within the last three years?

Please evaluate various features of the course you have just completed. Your comments will be kept confidential. The information you provide here will be combined with that from other trainees and summarized for the sponsor, the U.S. Department of Energy. Results from this evaluation will be used to improve this course.

\section{Course Content}

Overall, as a result of this course I believe that I:

developed specific skills and competencies in

occupational safety compliance that I can use on the job. ...5

gained a greater understanding of 29 CFR 1910 ,

Occupational Safety and Health Standards. .5

gained factual knowledge about

Federal safety and health program requirements .5

would recommend this course to others.

5

compliance knowledge gained from this course

will make work environments safer. .5

4

3

2

1

\section{Testing Materials}

The final test was a good measure of the knowledge gained in the course.

Strongly

Agree Agree

5

The final test (and pre-test) thoroughly covered materials and instruction presented in the course. .5

The final test (and pre-test) should become a permanent part of this course.
Nelther Agree nor DIsagree Disagree

Strongly

Disagree 


\section{Topic Areas}

Please evaluate each topic area using the 5-point scale below.
5 Excellent 4 Very Good
3 Good
2 Satisfactory 1 Unsatisfactory

Content

Instructor

Introduction to DOE safety and health program

$\begin{array}{lllll}.5 & 4 & 3 & 2 & 1 \\ .5 & 4 & 3 & 2 & 1 \\ .5 & 4 & 3 & 2 & 1 \\ .5 & 4 & 3 & 2 & 1 \\ .5 & 4 & 3 & 2 & 1 \\ .5 & 4 & 3 & 2 & 1 \\ .5 & 4 & 3 & 2 & 1 \\ .5 & 4 & 3 & 2 & 1 \\ .5 & 4 & 3 & 2 & 1 \\ .5 & 4 & 3 & 2 & 1 \\ .5 & 4 & 3 & 2 & 1 \\ .5 & 4 & 3 & 2 & 1 \\ .5 & 4 & 3 & 2 & 1 \\ .5 & 4 & 3 & 2 & 1 \\ .5 & 4 & 3 & 2 & 1 \\ .5 & 4 & 3 & 2 & 1 \\ .5 & 4 & 3 & 2 & 1 \\ .5 & 4 & 3 & 2 & 1 \\ .5 & 4 & 3 & 2 & 1 \\ .5 & 4 & 3 & 2 & 1 \\ .5 & 4 & 3 & 2 & 1 \\ .5 & 4 & 3 & 2 & 1 \\ .5 & 4 & 3 & 2 & 1 \\ .5 & 4 & 3 & 2 & 1 \\ .5 & 4 & 3 & 2 & 1 \\ .5 & 4 & 3 & 2 & 1 \\ .5 & 4 & 3 & 2 & 1 \\ .5 & 4 & 3 & 2 & 1 \\ .5 & 4 & 3 & 2 & 1 \\ .5 & 4 & 3 & 2 & 1 \\ .5 & 4 & 3 & 2 & 1\end{array}$

$\begin{array}{lllll}5 & 4 & 3 & 2 & 1\end{array}$

Introduction to OSHA standards

$\begin{array}{lllll}5 & 4 & 3 & 2 & 1\end{array}$

Hazardous materials_flammable and combustible materials ......

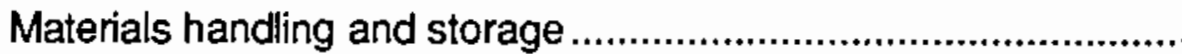

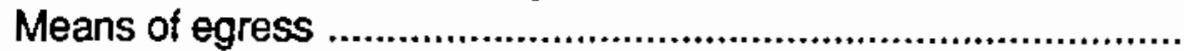

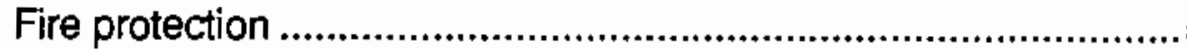

Compressed gas/air equipment ....................................................

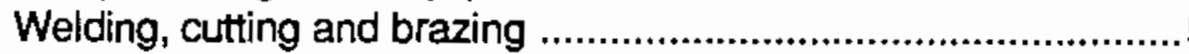

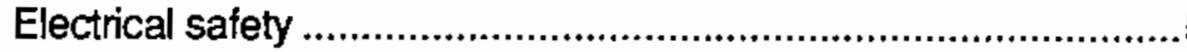

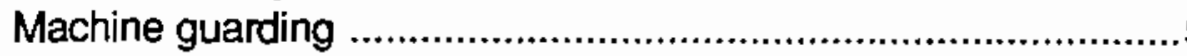

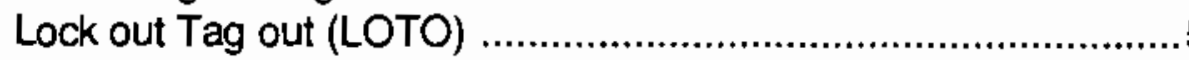

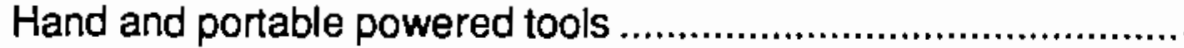

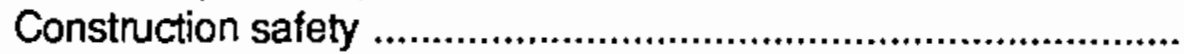

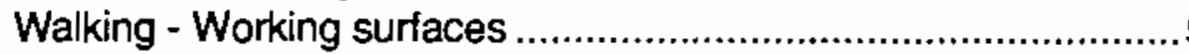

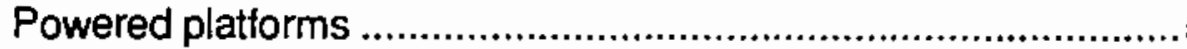

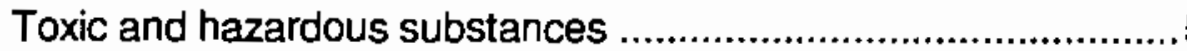

Carcinogen policy and model standards ....................................

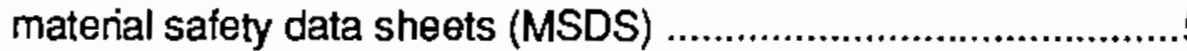

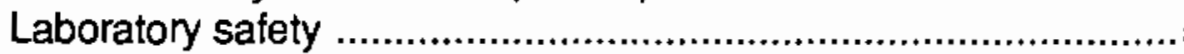

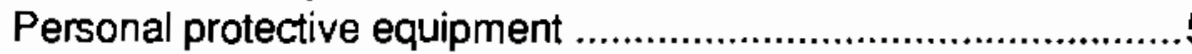

Medical and first aid ...............................................................

Occupational health and environmental control ...........................

Confined space entry ..............................................................

General and environmental controls ........................................

DOE accidentínjury/illness reporting system .............................5

Accident investigation procedures ...............................................

Inspection responsibilities and procedures ................................

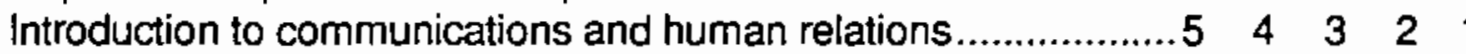

Safety inspection field exercise ................................................... 5 4 $4 \begin{array}{llll}3 & 2 & 1\end{array}$

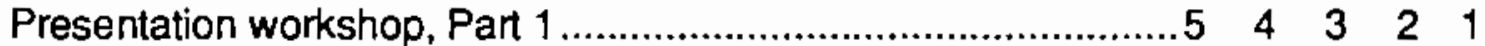

Presentation workshop, Part II.............................................

\section{Trainee Comments}

Please briefly describe how your expectations of this course were or were not met.

The most helpful topics covered or activities presented in this course were: 
The least helpful things discussed or done were:

More emphasis should be given to:

Less emphasis should be given to:

What I had hoped would be covered but wasn't mentioned was:

What specific suggestions do you have for improving future sessions.

What the presenters might do?

What the participants might do?

Other materials to supplement or substitute for the provided handouts?

Daily schedule/timing of activities, worktime?

Facilities/training room arrangements?

What other types of safety training courses would you like to see available?

Any further comments? 
.

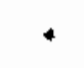




\section{DISTRIBUTION}

No. of

Copies

OFFSITE

12 DOE/Office of Scientific and Technical Information

R. J. Bowser

Office of Safety and Quality Programs

U.S. Department of Energy 19901 Germantown Rd.

Germantown, MD 20874

C. S. O'Dell

Division of Worker \& Facility Safety

U.S. Department of Energy

19901 Germantown Rd.

Germantown, MD 20874

J. W. Teske

Division of Worker \& Facility Safety

U.S. Department of Energy

19901 Germantown Rd.

Germantown, MD 20874
No. of

Copies

ONSITE

DOE Richland Operations office

P. W. Kruger

Il Pacific Northwest Laboratory

J. L. Anderson

H. N. Bowers

M. J. Farabaugh

J. A. Piatt

R. W. Vinther

Publishing Coordination

Technical Report Files (5)

Distr. I 
•

. 